\title{
Zaburzenia rozwojowe szkliwa i ich związek z występowaniem próchnicy zębów - przegląd piśmiennictwa
}

\author{
Developmental defects in enamel and their association with dental caries \\ - literature review \\ ${ }^{1}$ Wojskowa Specjalistyczna Przychodnia Lekarska SPZOZ Poznań \\ ${ }^{2}$ Katedra i Klinika Stomatologii Dziecięcej, Uniwersytet Medyczny im. Karola Marcinkowskiego w Poznaniu
}

DOI: http://dx.doi.org/10.20883/df.2017.8

\begin{abstract}
Streszczenie
W ostatnich latach pojawiło się wiele doniesień na temat etiologii i epidemiologii defektów rozwojowych szkliwa. Część tych zmian ma bowiem poważne implikacje kliniczne, stanowiąc problem estetyczny i funkcjonalny, a także obniżając odporność tkanek zębów na szkodliwe czynniki środowiska. Szeroko dyskutowane jest zagadnienie wpływu zaburzeń rozwojowych szkliwa na ryzyko rozwoju próchnicy zębów. Niektórym rodzajom defektów, takim jak hipomineralizacja trzonowcowo-siekaczowa czy hipoplazje szkliwa, przypisuje się zwiększanie ryzyka próchnicy, podczas gdy zmianom o charakterze łagodnej fluorozy zazwyczaj towarzyszy niższa podatność na próchnicę. W pracy, na podstawie dostępnego piśmiennictwa, scharakteryzowano różne grupy enamelopatii, z uwzględnieniem danych na temat ich związku z rozwojem próchnicy zębów.
\end{abstract}

Słowa kluczowe: zaburzenia rozwojowe szkliwa, hipomineralizacja, hipoplazja, próchnica zębów.

\begin{abstract}
In recent years numerous reports concerning the etiology and epidemiology of developmental defects in enamel have been published. This is because certain types of these lesions have important clinical implications, bringing about esthetic and functional problems, as well as decreasing the resistance of hard dental tissues to dental caries. The issue of the effects of enamel defects on the risk of dental caries has been also widely discussed. Some abnormalities, such as molar-incisor hypomineralization or enamel hypoplasia, are thought to increase the risk of caries, while mild fluorosis is associated with lower dental caries susceptibility. In the paper, on the basis of the available literature, various groups of enamel defects and their association with dental caries are described.
\end{abstract}

Keywords: developmental defects of enamel, hypomineralization, hypoplasia, dental caries.

\begin{abstract}
Wstęp
Szkliwo zębów, w przeciwieństwie do innych zmineralizowanych tkanek, nie ulega remodelowaniu. Zatem wszelkie zaburzenia funkcji komórek szkliwotwórczych pozostawiać mogą trwały ślad w strukturze i jakości tej tkanki w postaci tzw. defektów rozwojowych szkliwa. Wyróżniamy dwie podstawowe grupy tego rodzaju zaburzeń: hipoplazję, manifestującą się zmniejszoną grubością szkliwa oraz hipomineralizację w postaci zmętnień szkliwa. Pod względem klinicznym szkliwo z hipomineralizacją ma prawidłową grubość, ale zmienioną przezierność, która jest widoczna jako białe, żółte lub brązowe plamy (zmętnienia) [1-3].

Enamelopatie mogą mieć znaczący wpływ na zdrowie jamy ustnej, estetykę tkanek twardych, wrażliwość zębów oraz funkcje układu stomatognatycznego. Ponadto, zgodnie z wieloma doniesieniami, niektóre z nich mogą zwiększać ryzyko rozwoju erozji szkliwa i próchnicy zębów [4-7].
\end{abstract}

W pracy, na podstawie dostępnego piśmiennictwa, scharakteryzowano różne grupy defektów rozwojowych, z uwzględnieniem danych na temat ich związku z występowaniem próchnicy zębów.

\section{Zaburzenia uwarunkowane genetycznie}

Wady rozwojowe szkliwa uwarunkowane genetycznie obserwowane są zdecydowanie rzadziej od nabytych i zazwyczaj dotyczą wszystkich zębów mlecznych i stałych $[3,8]$.

Istnieje niemal 100 dziedzicznych jednostek chorobowych, w których występują defekty rozwojowe szkliwa. Grupę, w której enamelopatiom nie towarzyszą zaburzenia ze strony innych tkanek, określamy tradycyjnie mianem niecałkowitego rozwoju szkliwa (amelogenesis imperfecta, Al). Wyróżniamy wiele typów i podziałów Al w zależności od sposobu dziedziczenia, obrazu klinicznego, radiologicznego i zmian histopatolo- 
gicznych. Częstość występowania zaburzenia jest zróżnicowana w zależności od badanej populacji i waha się od 1/700 do 1/14000 [8, 9]. Powszechnie stosowana jest klasyfikacja Witkopa, wyróżniająca cztery postacie tej wady: typ I hipoplastyczny, stanowiący 60-70\% przypadków; typ II, zwany hipomaturacyjnym; rozpoznawany u około 20-30\% osób, typ III - hipokalcyfikacyjny, związany z niedowapnieniem szkliwa u około $7 \%$ osób dotkniętych wadą oraz najrzadszy typ IV hipoplastyczno-hipomaturacyjny, współwystępujący z taurodontyzmem $[9,10]$.

Klinicznie u osób z Al stwierdza się rozmaite zmiany, wahające się od ścieńczenia prawidłowej powierzchni szkliwa, przez szorstką powierzchnię, dołki, bruzdy, pigmentacje, zmętnienia, aż do zlokalizowanego braku szkliwa. Głównym problemem pacjentów jest niesatysfakcjonujący wygląd uzębienia, nadwrażliwość zębiny oraz obniżenie wysokości zwarcia w wymiarze pionowym ze względu na szybkie ścieranie się słabo zmineralizowanych tkanek. Leczenie pacjentów z wadami rozwojowymi szkliwa jest wielospecjalistyczne i zależy od stopnia nasilenia nieprawidłowości od najbardziej zachowawczego przy użyciu materiałów zapewniających podstawową estetykę do protetycznych kompleksowych rekonstrukcji uzębienia [11-13].

Zdania na temat podatności na próchnicę u pacjentów cierpiących na Al są podzielone. Zgodnie z informacjami zawartymi w przewodniku Amerykańskiej Akademii Stomatologii Dziecięcej (AAPD) w przypadku tego schorzenia mamy do czynienia ze zmniejszoną podatnością na próchnice [14], natomiast w piśmiennictwie opisywane są także przypadki Al z ostrym przebiegiem próchnicy zębów, która pogłębia zaawansowaną destrukcję tkanek twardych, związaną z samym defektem rozwojowym [15]. Za szybką progresję próchnicy odpowiadać mogą zarówno chropowata powierzchnia szkliwa sprzyjająca akumulacji płytki nazębnej, jak i źle zmineralizowane szkliwo. Jednocześnie badania histologiczne wykazały, że zębina u osób z hipokalcyfikacyjnym typem Al jest zbliżona morfologicznie do zmineralizowanej zębiny sklerotycznej [16]. Hiperkalcyfikacja zębiny obniża wprawdzie skuteczność technik adhezyjnych w odbudowie zębów z Al, ale jednocześnie może spowalniać proces próchnicowej destrukcji tkanek.

\section{Zaburzenia nabyte}

Enamelopatie nabyte mogą dotyczyć pojedynczych zębów, grup zębowych rozwijających się podczas działania czynnika sprawczego albo całego uzębienia $[3,17]$. Ten sam czynnik może powodować różnego rodzaju zaburzenia w zależności od stadium amelogenezy, a jednocześnie podobny defekt może być spowodowany różnymi czynnikami $[2,3,17]$.

Proces formowania szkliwa przebiega dwuetapowo i składa się z fazy wydzielniczej oraz fazy dojrzewania. Podczas pierwszej fazy wydzielana jest macierz szkliwa, składająca się z białek tworzących środowisko sprzyjające krystalizacji. Zakłócenie funkcji ameloblastów w tej fazie prowadzi do zredukowania grubości szkliwa (zmiany typu hipoplastycznego). Szkodliwe czynniki działające w fazie dojrzewania szkliwa prowadzić mogą do powstania hipomineralizacji w postaci zmętnienia szkliwa [2, 3, 8, 17].

Wśród czynników odpowiedzialnych za powstawanie nabytych zaburzeń wyróżniamy czynniki systemowe (prenatalne, perinatalne i postnatalne), środowiskowe (fluorki, dioksyny) oraz miejscowe (urazy lub infekcje okołowierzchołkowe wokół zębów mlecznych) $[3,8,17]$.

\section{Hipoplazja}

Hipoplazja jest ilościowym defektem szkliwa. Klinicznie przyjmuje postać dołków, rowków, półksiężycowatych ubytków brzegu siecznego i powierzchniowego braku szkliwa widocznego na koronie zębowej. W badaniu klinicznym szkliwo wykazuje prawidłową twardość [3, 8].

Hipoplazja jest niespecyficzną reakcją morfologiczną na różnego typu zaburzenia ogólnoustrojowe $[2,3,8,17,18]$. Na szczególną uwagę zasługują wcześniaki, które zmagają się z szeregiem problemów metabolicznych. Szacuje się, że u wysokiego odsetka wcześniaków (18 - 43\%) występują hipoplastyczne ubytki szkliwa [19]. Do czynników zaangażowanych w patogenezę uszkodzeń szkliwa $w$ tej grupie pacjentów zaliczamy niedotlenienie, niedobory wapnia i fosforu, cukrzycę matki oraz hiperbilirubinemię [17-19].

Hipoplazja może dotyczyć wielu zębów (w odpowiedzi na czynnik systemowy działający przez dłuższy czas) lub pojedynczego zęba (gdy czynnik uszkadzający działa miejscowo). Uważa się, że izolowane zaburzenia formowania szkliwa zębów stałych wiążą się najczęściej ze stanami zapalnymi lub urazami ich mlecznych poprzedników [2, 3, 8, 17] (Rycina 1).

Wadliwe szkliwo ma większą podatność na próchnicę (Rycina 1). Jest to związane ze skróceniem czasu potrzebnego na demineralizację tkanek twardych, które odbiegają normą od prawidłowej grubości $[4,20]$. Na szkliwie zębów dotkniętych hipoplazją, na których pojawiają się dołki, rowki i zagłębienia, łatwiej dochodzi do akumulacji płytki nazębnej [5, 7, 21]. 


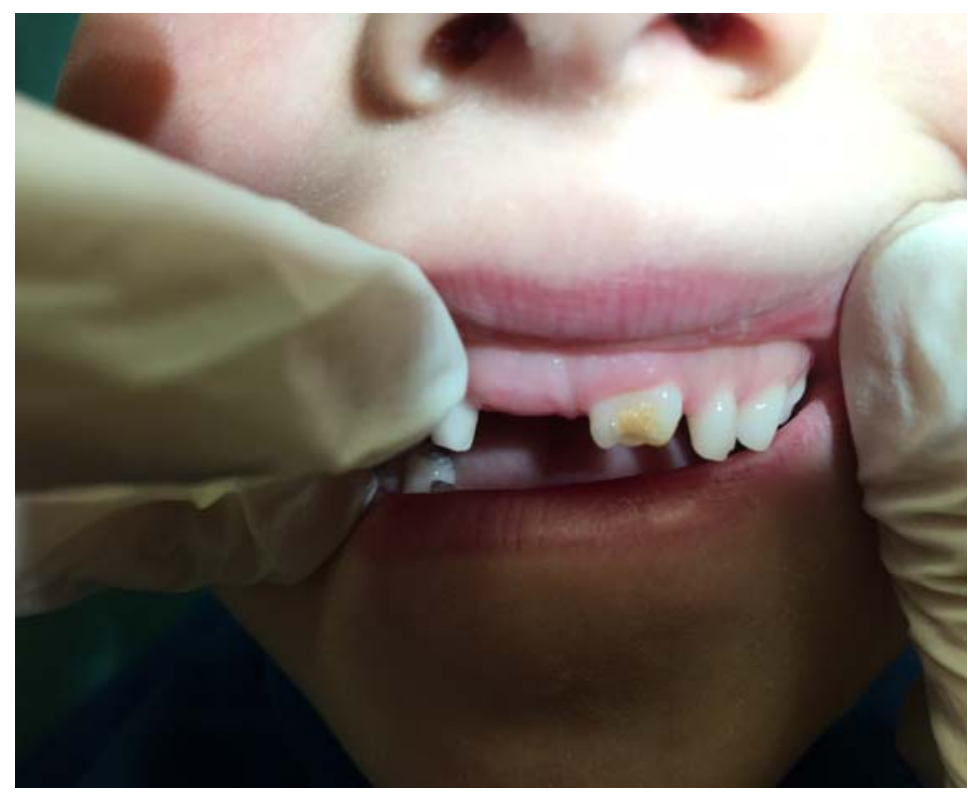

Rycina 1. Hipoplazja szkliwa powikłana próchnicą w zębie 21 u sześcioletniego pacjenta

Figure 1. Enamel hypoplasia complicated by caries of tooth 21 in a six-year old patient

\section{Hipomineralizacja}

Hipomineralizacja jest defektem jakościowym szkliwa. Rozróżniamy dwa typy tego zaburzenia: rozproszone lub ograniczone zmętnienie (nieprzezierność). Ograniczone zmętnienia są wyraźnie odgraniczone od zdrowego szkliwa, natomiast zmętnienia rozproszone nie posiadają widocznej granicy $[1,2,3,8]$.

Etiologia nieprzezierności rozproszonych (ang. diffuse opacities) jest związana z toksycznym efektem działania fluorków podczas rozwoju zęba (fluoroza szkliwa), chociaż do podobnych zmian prowadzić może również przyjmowanie amoksycyliny w pierwszych latach życia oraz niedobory pokarmowe $[1-3,8,17,20]$. Do rozpoznania fluorozy zębów upoważnia zatem nie tylko sam wygląd szkliwa, lecz także dodatkowe informacje uzyskane podczas wywiadu, wskazujące na zwiększoną podaż związków fluoru.

Klinicznie zmiany fluorotyczne mają postać białych linii lub plam bez wyraźnej granicy ze szkliwem zdrowym. Charakteryzują się podpowierzchniową hipomineralizacją szkliwa pokrytą szkliwem prawidłowo zmineralizowanym. Są wynikiem niecałkowitej resorpcji amelogenin podczas fazy dojrzewania szkliwa. W obrazie histopatologicznym stwierdza się nietypowe ułożenie i rozszczepienie pryzmatów szkliwnych oraz brak substancji międzypryzmatycznej, w miejscu której odkłada się barwnik brunatny. Zębina jest słabiej zmineralizowana i zawiera szerokie przestrzenie międzykuliste. W zaawansowanych sta- diach szkliwo może być matowe, nieprzezroczyste i chropowate [22-24].

Zawartość fluoru w szkliwie zwiększa się wraz ze wzrostem stopnia fluorozy. Tworzący się fluorohydroksyapatyt ma wyższy poziom krytyczny pH, przez co zmniejsza się szybkość rozpuszczania tkanki $[23,24]$. $Z$ tego względu łagodnym postaciom fluorozy przypisuje się zwykle zmniejszoną podatność na próchnicę. Natomiast w ciężkich postaciach fluorozy, gdy dochodzi do nasilonych zmian w strukturze szkliwa, obserwowano często większą podatność na działanie czynników próchnicotwórczych [25]. Badania laboratoryjne dowodzą, że szkliwo dotknięte fluorozą umiarkowaną wykazuje zwiększoną odporność na próchnicę, natomiast zębina $w$ łagodnych i umiarkowanych postaciach fluorozy jest bardziej podatna na demineralizację [26].

Zmętnienia ograniczone (ang. demarcated opacities), podobnie jak inne rodzaje defektów, mogą dotyczyć pojedynczego zęba lub wielu zębów i są związane z tym samym spektrum czynników etiologicznych co hipoplazja szkliwa.

Pojedynczy defekt zęba stałego (ząb Turnera) jest najczęściej związany z urazem lub stanem zapalnym tkanek okołowierzchołkowych jego mlecznego poprzednika [3, 17] (Rycina 2). Natomiast przykładem defektu pochodzenia ogólnoustrojowego jest hipomineralizacja trzonowcowo-siekaczowa (ang. molar-incisor hipomineralization, $\mathrm{MIH})$, manifestująca się uszkodzeniem jednego do czterech pierwszych zębów trzonowych stałych, a często również stałych siekaczy [2]. Etio- 


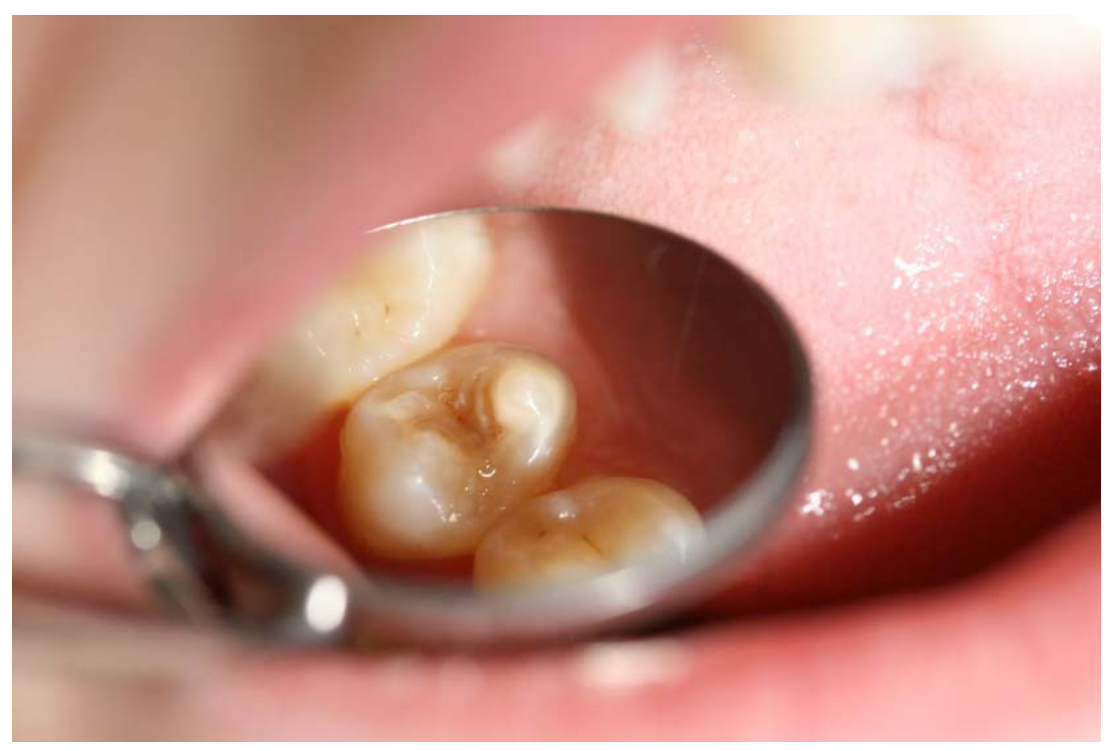

Rycina 2. Ząb 15 z demineralizacją próchnicową wadliwego szkliwa u 11-letniej pacjentki. Do hipomineralizacji szkliwa doszło w wyniku przewlekłego zapalenia tkanek okołowierzchołkowych wokół zęba 55 (ząb Tunera)

Figure 2. Tooth 15 with cariotic demineralization of abnormal enamel in an 11-year-old patient. Enamel hypomineralisation resulting from chronic periapical inflammation of tooth 55 (Turner's tooth)

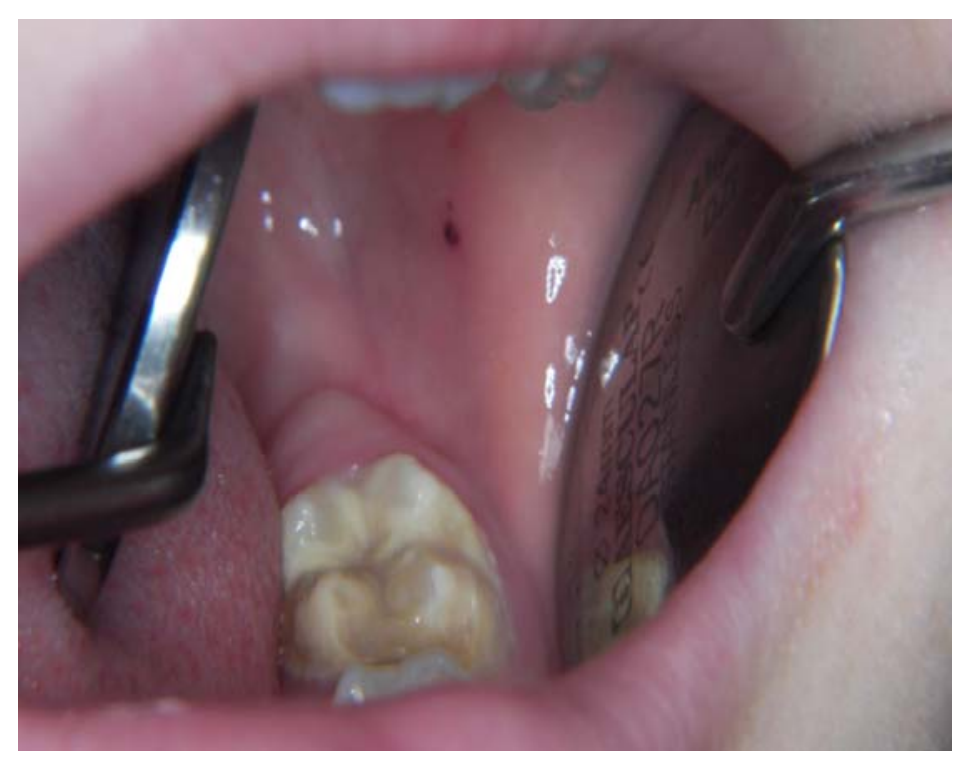

Rycina 3. Miękkie, podatne na próchnicę i uszkodzenia mechaniczne szkliwo w zębie 36 u siedmioletniej pacjentki z hipomineralizacją trzonowcowo-siekaczową

Figure 3. Soft, susceptible to caries and mechanical damage enamel to tooth 36 in a seven-year-old patient with molar-incisor hipomineralisation

logia tej wady związana jest z czynnikami pre-, peri- i postnatalnymi. Uważa się także, że bardziej narażone na występowanie hipomineralizacji trzonowcowo-siekaczowej są dzieci, u których do 3-4 roku życia występowały problemy zdrowotne. Do czynników ryzyka MIH zalicza się choroby układu oddechowego, astmę, zapalenie ucha środkowego, zapalenie migdałków, różyczkę, ospę wietrz- ną, odrę, uszkodzenia mózgu, mukowiscydozę, zespół nerczycowy, radioterapię, zaburzenia żołądkowo-jelitowe, zaburzenia gospodarki wapniowo-fosforanowej, niedobory żywieniowe, antybiotykoterapię oraz ekspozycję na dioksyny $[2,3,8$, 17, 27-29].

Najbardziej charakterystyczne zmiany w obrazie klinicznym to białe, żółte lub brązowe plamy 
na powierzchniach policzkowych i żujących zębów trzonowych, wyraźnie odgraniczone od prawidłowego szkliwa. Szkliwo w obrębie plam jest porowate i kruche. Łatwo ulega uszkodzeniom mechanicznym, np. podczas aktu żucia. Odpryski szkliwa pojawiają się przede wszystkim w zębach trzonowych. Mniej narażone na uszkodzenia podczas żucia jest szkliwo zębów siecznych [2].

Badania potwierdzają jednoznacznie wpływ MIH na rozwój zmian próchnicowych [2, 4, 7, 30] (Rycina 3). Szkliwo zębów dotkniętych hipomineralizacją trzonowcowo-siekaczową jest bardziej porowate i miękkie. Sprzyja to akumulacji płytki nazębnej, która prowadzi do rozwoju próchnicy. Uszkodzone szkliwo odsłania zębinę, przez co szybciej dochodzi do rozprzestrzeniania się zmian demineralizacyjnych. Niesatysfakcjonujący wygląd kliniczny zębów dotkniętych MIH oraz ich wysoka podatność na próchnicę skutkują znaczącym zwiększeniem potrzeb leczniczych w grupie pacjentów dotkniętych tym rodzajem defektu, z koniecznością prowadzenia leczenia endodotycznego, protetycznego, a niekiedy nawet ekstrakcji zniszczonych zębów [27-30].

\section{Podsumowanie}

Zaburzenia rozwojowe szkliwa stanowią istotny problem kliniczny, a możliwości zapobiegania ich powstawaniu są ograniczone. Poza kontrolą ekspozycji na fluorki, profilaktyką próchnicy zębów mlecznych i ich urazów oraz unikaniem stosowania leków prowadzących do zaburzeń funkcji ameloblastów, pozostaje, trudne do wyeliminowania, całe spektrum wydarzeń zdrowotnych i losowych, które mogą doprowadzić do wytworzenia wadliwej struktury szkliwa. Leczenie enamelopatii jest często skomplikowane ze względu na nadwrażliwość odsłoniętej zębiny, trudności w uzyskaniu optymalnego efektu estetycznego i obniżoną skuteczność systemów adhezyjnych. Problem stanowi także podatność zmienionych tkanek na próchnicę, wczesne pojawianie się ognisk próchnicy pierwotnej i wtórnej oraz szybka progresja zmian. Jak wynika z przedstawionego piśmiennictwa, defekty nabyte o charakterze niedorozwoju szkliwa i ograniczonego zmętnienia sprzyjają rozwojowi procesu próchnicowego, natomiast poglądy na temat odporności na próchnicę zmian o charakterze fluorozy i genetycznie uwarunkowanej Al nie są jednoznaczne. Niezależnie jednak od potencjalnego związku defektu z występowaniem próchnicy, jego obecność wskazuje na konieczność objęcia pacjenta programem regularnych wizyt kontrolnych, które pozwalają na wczesne wdrożenie odpowiednich działań profilaktycznych i leczniczych.

\section{Oświadczenia}

Oświadczenie dotyczące konfliktu interesów

Autorki deklarują brak konfliktu interesów w autorstwie oraz publikacji pracy.

\section{Źródła finansowania}

Autorki deklarują brak źródeł finansowania.

\section{Piśmiennictwo}

[1] Clarkson J, O'Mullane D. A Modified DDE Index for Use in Epidemiological Studies of Enamel Defects. J Dent Res. 1989;68(3):445-450.

[2] Crombie F, Manton D, Kilpatrick N. Etiology of molar-incisor hypomineralization: a critical review. Int $\mathrm{J} \mathrm{Pa-}$ ediatr Dent. 2009;19(2):73-83.

[3] Wong HM. Aetiological Factors for Developmental Defects of Enamel. Austin J Anat. 2014;1(1):1003.

[4] Opydo-Szymaczek J, Gerreth K. Developmental Enamel Defects of the Permanent First Molars and Incisors and Their Association with Dental Caries in the Region of Wielkopolska. Oral Health Prev Dent. 2015;13(5):461-469.

[5] Hong L, Levy SM, Warren JJ, Broffitt B. Association between enamel hypoplasia and dental caries in primary second molars: a cohort study. Caries Res. 2009;43(5):345352.

[6] Kazoullis S, Seow WK, Holcombe T, Newman B, Ford D. Common dental conditions associated with dental erosion in schoolchildren in Australia. Pediatr Dent. 2007;29(1):33-39.

[7] Vargas-Ferreira F, Salas MM, Nascimento GG, Tarquinio $\mathrm{SB}$, Faggion CM, Peres MA, Thomson WM, Demarco FF. Association between developmental defects of enamel and dental caries: A systematic review and meta-analysis. J Dent. 2015;43(6):619-628.

[8] Anthonappa RP, King NM. Enamel Defects in the Permanent Dentition: Prevalence and Etiology. Planning and Care for Children and Adolescents with Dental Enamel Defects. Berlin Heidelberg: Springer; 2015. s. 15-30.

[9] Wright JT. Amelogenesis Imperfecta: Current Understanding of Genotype-Phenotype. Planning and Care for Children and Adolescents with Dental Enamel Defects. Berlin Heidelberg: Springer; 2015. s. 59-72.

[10] Crawford P, Aldred M, Bloch-Zupan A. Amelogenesis imperfecta. Orphanet J Rare Dis. 2007;4:2-17.

[11] Koruyucu M, Bayram M, Bahar Tuna E, Gencay K, Seymen $F$. Clinical findings and long-term managements of patients with amelogenesis imperfect. Eur $\mathrm{J}$ Dent. 2014;8(4):546-552.

[12] Zadurska M, Siemińska-Piekarczyk B, Maciejak D, Remiszewski A, Grzybowski A, Gordon A, Wacińska-Drabińska M. Amelogenesis imperfecta w materiale Zakładu Ortodoncji i Zakładu Stomatologii Dziecięcej IS AM w Warszawie. Czas Stomatol. 2007; LX(10):684-690.

[13] Chaudhary M, Dixit S, Singh A, Kunte S. Amelogenesis imperfecta: report of a case and review of literature. J Oral Maxillofac Pathol. 2009;13(2):70-77.

[14] American Academy of Pediatric Dentistry. Guideline on Dental Management of Heritable Dental Developmental Anomalies. Tekst na stronie internetowej: http://www. aapd.org/media/policies_guidelines/g_ohcheritable.pdf. Data dostępu: 5.03.2017.

[15] Markovic D, Petrovic B, Peric T. Case series: Clinical findings and oral rehabilitation of patients with amelogenesis imperfect. Eur Arch Paediatr Dent. 2004;11(4):201-208.

[16] Sánchez-Quevedo MC, Ceballos G, García JM, Luna JD, Rodríguez IA, Campos A. Dentine structure and mineralization in hypocalcified amelogenesis imperfecta: a quantitative X-ray histochemical study. Oral Dis. 2004;10(2):94-98.

[17] Brook AH. Multilevel complex interactions between genetic, epigenetic and environmental factors in the aetiology of anomalies of dental development. Arch Oral Biol. 2009;54:3-17. 
[18] Seow WK, Perham S. Enamel hypoplasia in prematurely-born children: a scanning electron microscopic study. J Pedod. 1990;14(4):235-239.

[19] Pimlott JF, Howley TP, Nikiforuk G, Fitzhardinge PM. Enamel defects in prematurely born, low birth-weight infants. Pediatr Dent. 1985;7(3):218-223.

[20] Pascoe L, Seow WK. Enamel hypoplasia and dental caries in Australian Aboriginal children: prevalence and correlation between the two diseases. Pediatr Dent. 1994;16(3):193-199.

[21] Popoola BO, Onyejaka N, Folayan MO. Prevalence of developmental dental hard-tissue anomalies and association with caries and oral hygiene status of children in Southwest, Nigeria. BMC Oral Health. 2017;17:8. doi: 10.1186/s12903-016-0236-6.

[22] Hong L, Levy SM, Warren JJ, Dawson DV, Bergus GR, Wefel JS. Association of amoxicillin use during early childhood with developmental tooth enamel defects. Arch Pediatr Adolesc Med. 2005;159:943-948.

[23] Centers for Disease Control and Prevention. Recommendations for using fluoride to prevent and control dental caries in the United States. MMWR. 2001;50:1-42.

[24] Richard A, Ferjerskov O, Baelum V. Enamel fluoride in relation to severity of human fluorosis. Advances in Dental Research. 1989;3(2):147-53.

[25] Marín LM, Cury JA, Tenuta LM, Castellanos JE, Martignon S. Higher fluorosis severity makes enamel less resistant to demineralization. Caries Res. 2016;50(4):407-413.

[26] Waidyasekera PG, Nikaido T, Weerasinghe DD, Wettasinghe KA, Tagamia J. Caries susceptibility of human fluorosed enamel and dentine. J Dent. 2007;35:343-349.
[27] Daly D, Waldron JM. Molar incisor hypomineralisation: clinical management of the young patient. J Ir Dent Assoc. 2009;55:83-86.

[28] William V, Messer LB, Burrow MF. Molar Incisor Hypomineralization: Review and Recommendations for Clinical Management. Pediatr Dent. 2006;28:224-232.

[29] Weerheijm KL. Molar Incisor Hypomineralization (MIH): Clinical Presentation, Aetiology and Management. Dent Update. 2004;31:9-12.

[30] Jeremias F, de Souza JF, Silva CM, Cordeiro RC, Zuanon AC, Santos-Pinto L. Dental caries experience and Molar-Incisor Hypomineralization. Acta Odontol Scand. 2013; 71:870-876.

Zaakceptowano do edycji: 2017-04-12 Zaakceptowano do publikacji: 2017-04-22

\section{Adres do korespondencji:}

Collegium Stomatologicum UMP

ul. Bukowska 70, 60-812 Poznań

tel.: +48 618547053

e-mail: jopydo@ump.edu.pl 